\title{
Insecticidal activity of the extracts of Piper retrofractum fruit and Tephrosia vogelii leaf and their mixtures against Crocidolomia pavonana
}

\author{
Djoko Prijono $^{1 *}$, R. Dewi Ratna Wulan ${ }^{2}$, Ferdi $^{3}$, Nur Alfi Saryanah ${ }^{4}$ \\ ${ }^{1}$ Department of Plant Protection, Faculty of Agriculture, IPB University, Darmaga Campus, Bogor 16680, Indonesia \\ ${ }^{2}$ Agricultural Quarantine Agency Class II, Kendari 93114, Indonesia \\ ${ }^{3}$ Agricultural Quarantine Agency Class I, Pekanbaru 28131, Indonesia \\ ${ }^{4}$ Center for Agricultural Production Technology, Agency for the Assessment and Application of Technology, Puspiptek \\ Serpong, Tangerang Selatan 15314, Indonesia \\ *Corresponding Author: djokopr@ipb.ac.id
}

Received December 24, 2020; revised December 28, 2020; accepted December 29, 2020

\begin{abstract}
This laboratory work was carried out to evaluate the insecticidal activity of the extracts of Piper retrofractum (Piperaceae) fruit and Tephrosia vogelii (Fabaceae) leaf and their mixtures against the cabbage head caterpillar, Crocidolomia pavonana. Ground plant materials of the two plant species were extracted separately with n-hexane and methanol. The results of leafresidue feeding bioassays showed that $P$. retrofractum $(\mathrm{Pr})$ and $T$. vogelii $(\mathrm{Tv})$ hexane extracts had strong insecticidal activity against $C$. pavonana larvae $\left(\mathrm{LC}_{95}<0.5 \%\right)$ and were more active than their respective methanol extracts. $\mathrm{Pr}$ and $\mathrm{Tv}$ hexane extract had a moderate and a rather weak contact effect on $C$. pavonana larvae, respectively. In feeding tests, $\mathrm{Pr}+\mathrm{Tv}$ (1:1) hexane and methanol extract mixtures indicated synergistic joint effect both at $\mathrm{LC}_{50}$ and $\mathrm{LC}_{95}$ level, whereas in the contact test, the mixture of $\operatorname{Pr}+\operatorname{Tv}(1: 1)$ hexane extract was synergistic at the $\mathrm{LC}_{50}$ level but antagonistic at the $\mathrm{LC}_{95}$ level. In choice tests, antifeedant effects of $\mathrm{Pr}$ and $\mathrm{Tv}$ hexane extracts at $\mathrm{LC}_{25}$ to $\mathrm{LC}_{70}$ levels on $C$. pavonana larvae followed a concentration-dependent fashion. Thus, separate or mixed $P$. retrofractum and $T$. vogelii extracts are potential alternatives for the control of C. pavonana.
\end{abstract}

Keywords: Antifeedant, Botanical insecticides, Cabbage pest, Extract mixtures, Joint action

\section{ABSTRAK}

Aktivitas insektisida ekstrak buah Piper retrofractum dan daun Tephrosia vogelii serta campuran kedua ekstrak terhadap Crocidolomia pavonana

Penelitian ini dilakukan untuk menguji aktivitas insektisida ekstrak buah Piper retrofractum (Piperaceae) dan daun Tephrosia vogelii (Fabaceae) serta campuran kedua ekstrak tersebut terhadap ulat krop kubis, Crocidolomia pavonana. Serbuk bahan tumbuhan uji diekstrak secara terpisah dengan pelarut $n$-heksana dan metanol. Hasil pengujian dengan metode residu pada daun menunjukkan bahwa ekstrak heksana $P$. retrofractum $(\operatorname{Pr})$ dan $T$. vogelii $(\mathrm{Tv})$ memiliki aktivitas insektisida yang kuat terhadap larva $C$. pavonana $\left(\mathrm{LC}_{95}<0.5 \%\right)$ serta lebih aktif daripada ekstrak methanol masing-masinng. Ekstrak heksana Pr dan Tv masing-masing memiliki efek kontak sedang dan agak lemah terhadap larva C. pavonana. Pada pengujian dengan metode residu pada daun, campuran ekstrak $\operatorname{Pr}+\operatorname{Tv}(1: 1)$, baik yang disiapkan dengan pelarut heksana maupun metanol, bersifat sinergistik pada taraf $\mathrm{LC}_{50}$ dan $\mathrm{LC}_{95}$, sedangkan secara kontak, campuran ekstrak heksana $\operatorname{Pr}+\operatorname{Tv}(1: 1)$ bersifat sinergistik pada taraf $\mathrm{LC}_{50}$ tetapi antagonistik pada taraf $\mathrm{LC}_{95}$. Pada pengujian aktivitas makan dengan metode pilihan, efek penghambatan makan ekstrak heksana Pr dan Tv pada konsentrasi yang setara $\mathrm{LC}_{25}$ sampai $\mathrm{LC}_{70}$ makin meningkat dengan makin tingginya konsentrasi yang diuji. Dengan demikian, ekstrak tunggal atau campuran ekstrak $P$. retrofractum dan $T$. vogelii potensial untuk digunakan sebagai bahan insektisida alternatif dalam pengendalian hama $C$. pavonana.

Kata Kunci: Campuran ekstrak, Hama kubis, Insektisida nabati, Penghambat makan, Sinergisme

\section{INTRODUCTION}

Javanese long pepper (JLP) Piper retrofractum Vahl (Piperaceae), a source of spices and herbal medicines, is a potential source of botanical insecticides that has long been cultivated in Java, Indonesia (Heyne, 1987; Utami \& Jansen, 1999). JLP fruit extracts have been reported to possess strong insecticidal activity against various insect pests including European earwigs Forficula auricularia (Assabgui et al., 1997), cabbage head caterpillar Crocidolomia pavonana (Prijono et al., 2006; Nurfajrina \& Prijono, 2015), green stinkbug Nezara viridula (Hasnah \& Rusdy, 2015), tropical armyworm Spodoptera litura (Yooboon et al., 2019), papaya mealybug Paracoccus marginatus (Asnan et al., 2015), tea mosquito bug Helopeltis antonii (Indriati et al., 2015), and rice brown planthopper Nilaparvata lugens (Nuryanti et al., 2018).

Another plant species that has long been used as a source of botanical insecticides is fish-poison bean (FPB), Tephrosia vogelii J.D. Hooker (Fabaceae) (Gaskins et al., 1972; Sunarno, 1997; Stevenson et al., 2017). FPB leaf preparations have been reported to have good insecticidal activity 
against some field crop and stored-product pests (Prakash \& Rao, 1997; Dadang \& Prijono, 2011; Kamanula et al., 2011; Stevenson \& Belmain, 2017). Rotenoids such as deguelin, tephrosin, and rotenone are the primary constituents responsible for the insecticidal activity of FPB leaves (Delfel et al., 1970; Stevenson et al., 2012).

JLP fruits have been reported to contain more than 15 piperamides (Kikuzaki et al., 1993; Parmar et al., 1997) including guineensine, pellitorine, pipercide, piperine, and retrofractamide A. These compounds have also been isolated from other Piperaceae plants and were shown to have insecticidal activity (Miyakado et al., 1989; Scott et al., 2008). Moreover, a mixture of pipercide, dihydropipercide, and guineensine showed high synergistic activity against the pulse beetle Callosobruchus chinensis (Miyakado et al., 1989). These three piperamides have methylenedioxyphenyl (MDP) moieties in their molecules which is a characteristic of insecticide synergists that can inhibit cytochrome P450 enzymes (Bernard \& Philogène 1993). These enzymes commonly involve in the detoxification of toxic compounds in the body (Chen, 2020). Thus, in addition to possessing insecticidal activity itself, JLP extract which contains substances possessing MDP moieties is also expected to yield synergistic activity when mixed with other plant extracts.

Previously, Dadang and Prijono (2011) reported that mixtures of methanol extracts of JLP and FPB at concentration ratios of 2:1, 1:1, and 1:2 were more toxic than separate extracts to $C$. pavonana. They, however, did not analyze joint action of those extract mixtures quantitatively. This work was conducted to evaluate the insecticidal activity of hexane and methanol extracts of JLP fruits and FPB leaves as well as to analyze joint action of JLP and FPB extract mixtures against $C$. pavonana larvae. Extracts of the two species were also tested separately for their antifeedant effect.

\section{MATERIALS AND METHODS}

\section{Collection of Insecticidal Plant Materials}

Dry JLP fruits were purchased from a medicinal herb kiosk at a local market in Bogor. FPB leaves were collected from Caringin District, Bogor Regency, West Java (6 $44^{\prime} 44.7^{\prime \prime} \mathrm{S}$ and $106^{\circ} 49^{\prime} 57.5^{\prime \prime}$ E longitude; $636 \mathrm{~m}$ asl). They were immediately cut to small pieces and air-dried for one week in a laboratory space protected from direct exposure to sunlight.

\section{Rearing of Test Insects}

C. pavonana colony was maintained at the Laboratory of Insect Physiology and Toxicology, Department of Plant Protection, Bogor Agricultural University following the procedures as described by Prijono and Hassan (1992). Briefly, C. pavonana larvae were fed pesticide-free broccoli leaves and the adults were provided with $10 \%$ honey solution absorbed to a cotton swab.

\section{Extraction of Plant Materials}

Air-dried JLP fruit cuts and FPB leaf cuts were pulverized separately with a blender and then sieved with a $0.5 \mathrm{~mm}$ mesh sieve. Ground JLP fruits and FPB leaves, $300 \mathrm{~g}$ each, were separately extracted with 21 of $n$-hexane or methanol by infusion method (Houghton \& Raman, 1998). Each extract was filtered with Whatman No. 41 filter paper and the extraction was repeated until the filtrate was clear. The filtrates were pooled and the solvent was evaporated to dryness at $50{ }^{\circ} \mathrm{C}$ under reduced pressure in a rotary evaporator. After evaporation of the solvent, the JLP hexane extract consisted of two parts, i. e. liquid and solid parts, which were then separated physically. All extracts were kept in refrigerator $\left(4 \pm 0.5^{\circ} \mathrm{C}\right)$ until used for bioassays.

\section{Toxicity Tests}

The JLP hexane extract used in all bioassays was only the liquid fraction of the initial JLP hexane extract since its solid fraction was not active. Hereafter, the term JLP hexane extract refers to the liquid fraction of the initial JLP hexane extract.

\section{Leaf-dipping Tests}

Hexane and methanol extracts of JLP and FPB were tested separately against second-instar larvae $C$. pavonana at five concentration levels which were expected to give insect mortality in the range of about $15 \%$ to $95 \%$ as determined in preliminary tests (Robertson et al., 2017). Hexane extracts were mixed with acetone, methanol and an emulsifier Tween 80 (5:5:2, final concentration $1.2 \% \mathrm{v} / \mathrm{v})$, whereas methanol extracts were mixed with methanol and Tween 80 (5:1, 1.2\%), then were diluted with distilled water to the desired volume. Distilled water containing acetone, methanol and Tween 80 (5:5:2, $1.2 \%)$ or methanol and Tween $80(5: 1,1.2 \%)$ was used as control solution.

Fresh broccoli leaf portions $(4 \mathrm{~cm} \times 4 \mathrm{~cm})$ were dipped separately in a particular extract preparation to complete wetness. Control leaves were dipped in the relevant control solution. Treated and control leaf portions were placed separately in upsidedown glass petri dishes $(9 \mathrm{~cm}$ diameter) lined with tissue paper which extended to the space between top and bottom parts of each petri dish. Fifteen freshlymoulted second-instar larvae $C$. pavonana were placed in each petri dish containing a treated or control leaf portion. Each treatment was done with five replicates. Test larvae were allowed to feed on treated or control leaves for $48 \mathrm{~h}$ and then were fed untreated leaves for the next $24 \mathrm{~h}$. The number of dead larvae was counted daily until $72 \mathrm{~h}$ after treatment (HAT) and insect mortality data at 72 HAT were analyzed with probit method using PoloPlus (Robertson et al., 2003). 
Mixtures of JLP and FPB hexane extract as well as JLP and FPB methanol extract, at a 1:1 concentration ratio each, were also tested. Each extract mixture was tested at six concentration levels which were expected to give about $15 \%$ to $95 \%$ insect mortality. Each concentration treatment was done with five replicates. Procedures for treatment, insect mortality counts, and analysis of mortality data were the same as those in the tests with separate extracts.

The type of joint action of each extract mixture was determined based on the independent joint action model by calculating co-toxicity ratio (CTR) of each mixture following Robertson and Smith (1984). The type of joint action of extract mixtures was categorized as follows: (1) if CTR > 1.0, then synergistic joint action is indicated; (2) if CTR = 1.0 , then additive joint action is indicated; and (3) if $\mathrm{CTR}<1.0$, then antagonistic joint action is indicated.

\section{Contact Tests}

Hexane extracts of JLP and FPB were tested separately and as a 1:1 mixture at 5-6 concentration levels which were expected to give $15 \%$ to $95 \%$ insect mortality. Each test extract was diluted with acetone to the desired concentration. A particular extract solution at a volume of $0.5 \mathrm{ml}$ was pipetted into a glass vial ( $2.2 \mathrm{~cm}$ diameter and $5.8 \mathrm{~cm}$ high). The vial was then closed and swirled slantwise to coat the inner surface of the vial with the test extract solution. Excess of liquid was discarded and the vial was airdried in a fume hood. After the extract deposit in the vial dried up, 15 second-instar larvae $C$. pavonana (2$4 \mathrm{~h}$ after moulting) was put into the vial. The vial was then closed with muslin cloth and placed upside down in a tray. Control insects were placed in the vial treated with acetone only. After being exposed to the extract thin film for $2 \mathrm{~h}$, the test larvae were transferred to an upside-down petri dish sealed with tissue paper and fed with a fresh broccoli leaf portion $(4 \mathrm{~cm} \times 4 \mathrm{~cm})$. Insect mortality was recorded at 24 HAT and the mortality data was analyzed with probit method using PoloPlus (Robertson et al., 2003). The type of joint action of the extract mixture was determined by calculating co-toxicity ratio of the mixture as in the leaf-dipping tests.

\section{Antifeeding Tests}

Hexane extracts of JLP and FPB were used in the choice feeding tests against second-instar larvae $C$. pavonana. Each extract was tested at four concentrations equivalent to its $\mathrm{LC}_{25}$ to $\mathrm{LC}_{70}$ based on the results of the aforementioned leaf-dipping tests. Procedures for extract dilution were the same as in the leaf-dipping tests and five replicates were used for each extract concentration treatment.

Four broccoli leaf portions $(2.5 \mathrm{~cm} \times 2.5 \mathrm{~cm})$ were cut out from broccoli leaves on both sides of the leaf midrib. Leaf portions from one side of the midrib was used for the treatment and those from the other side for the corresponding control. Procedures for leaf treatment were the same as in the leaf-dipping tests. After air drying, two treated and two control leaf portions were placed alternatingly in an upside-down petri dish sealed with tissue paper. Ten second-instar larvae $C$. pavonana were released in the center of the petri dish. After $24 \mathrm{~h}$, areas of treated and control leaves eaten were measured using 1-mm square graph paper. Differences in areas of treated and control leaves eaten were analyzed by using paired $t$-test (Ott \& Longnecker, 2016).

The antifeedant effect (AF) of test extracts at each concentration level was calculated as follows (Dadang \& Prijono, 2008): AF $(\%)=\left[\left(\mathrm{A}_{\mathrm{CL}}-\right.\right.$ $\left.\left.\mathrm{A}_{\mathrm{TL}}\right) /\left(\mathrm{A}_{\mathrm{CL}}+\mathrm{A}_{\mathrm{TL}}\right)\right] \times 100 \%$ where $\mathrm{A}_{\mathrm{CL}}$ and $\mathrm{A}_{\mathrm{TL}}$ were the area of control and treated leaves eaten $\left(\mathrm{mm}^{2}\right)$, respectively. The antifeedant levels among different concentration treatments with each extract were analyzed by analysis of variance followed by Tukey's test (Ott \& Longnecker, 2016) using SAS statistical software package (SAS Institute 2018).

\section{RESULTS AND DISCUSSION}

\section{Extract Toxicity}

In leaf-dipping tests, hexane extracts of both JLP fruits and FPB leaves were about twice as active as their respective methanol extracts (Table 1). $\mathrm{LC}_{95}$ of both JLP and FPB hexane extracts were less than $0.5 \%$ suggesting that both extracts had strong insecticidal activity against $C$. pavonana larvae. Prijono (1999) indicated that a plant extract is considered to have strong insecticidal activity if the extract at concentrations of no more than $0.5 \%$ can give at least $80 \%$ kill in the test insect. Referring to this criteria, JLP and FPB methanolic extracts were considered to have sufficiently strong ( $\mathrm{LC}_{95}$ 0.6\%) and moderately strong ( $\mathrm{LC}_{95} 1.3 \%$ ), respectively, against $C$. pavonana larvae (Table 1). Thus, at the $\mathrm{LC}_{95}$ level JLP methanolic extract was more than twice as active as FPB methanolic extract. Previously, Dadang \& Prijono (2011) reported that in the feeding tests JLP methanolic extract was more active than FPB extract on $C$. pavonana larvae.

JLP and FPB hexane extracts which were more active than their respective methanol extracts might indicate that the former extracts contained proportionately higher amounts of more nonpolar active compounds. Kikuzaki et al. (1993) reported that JLP fruits contained a higher amount of guineensine which is more nonpolar and more active than the other known insecticidal constituents of JLP. In another study, Stevenson et al. (2012) reported that FPB chemotype 1 leaves contained more deguelin which is more nonpolar than the other insecticidal rotenoids such as tephrosin and rotenone. 
Table 1. Results of probit analysis of $C$. pavonana larval mortality treated with $P$. retrofractum fruit and $T$. vogelii leaf extracts and their mixtures in leaf-dipping tests, $72 \mathrm{~h}$ after treatment

\begin{tabular}{lccc}
\hline Extract & $b \pm \mathrm{SE}^{\mathrm{a}}$ & $\mathrm{LC}_{50}(95 \% \mathrm{CI})^{\mathrm{b}}(\%)$ & $\mathrm{LC}_{95}(95 \% \mathrm{CI})^{\mathrm{b}}(\%)$ \\
\hline P. retrofractum (JLP) & & & \\
Hexane & $3.97 \pm 0.44$ & $0.12(0.09-0.15)$ & $0.31(0.22-0.73)$ \\
Methanolic & $4.32 \pm 0.39$ & $0.25(0.20-0.30)$ & $0.60(0.47-1.00)$ \\
$T$. vogelii (FPB) & & & \\
Hexane & $4.23 \pm 0.45$ & $0.14(0.10-0.21)$ & $0.34(0.22-2.57)$ \\
Methanolic & $2.56 \pm 0.31$ & $0.30(0.26-0.34)$ & $1.30(0.94-2.18)$ \\
JLP + FPB (1:1) & & & \\
Hexane & $7.26 \pm 0.84$ & $0.15(0.14-0.16)$ & $0.26(0.23-0.31)$ \\
Methanolic & $4.37 \pm 0.40$ & $0.16(0.10-0.21)$ & $0.38(0.27-0.97)$ \\
\hline
\end{tabular}

${ }^{\mathrm{a}} b$ : slope of the probit line, SE: standard error.

${ }^{\mathrm{b}} \mathrm{CI}$ : confidence interval.

In leaf-dipping tests, FPB hexane extract had about the same level of activity as JLP hexane extract as shown by their similar $\mathrm{LC}_{50}$ and $\mathrm{LC}_{95}$ (Table 1 ). In contact tests (contact to extract thin film on a glass surface), however, JLP hexane extract was more active than FPB extract as indicated by the lower $\mathrm{LC}_{50}$ and $\mathrm{LC}_{95}$ of the former extract than the latter (Table 2 ). This difference was probably due to the better penetration of active compounds in JLP extract than those in FPB extract through the insect cuticle. This, in turn, could be due to the difference in polarity of the applied compounds (Matsumura, 1985). Dadang \& Prijono (2011) reported that JLP methanolic extract had a good contact effect (by topical application) on C. pavonana larvae but they did not test FPB extract. In leaf-dipping tests, mixtures of JLP and FPB hexane and methanolic extracts had strong insecticidal activity $\left(\mathrm{LC}_{95}<0.5 \%\right)$ against $C$. pavonana larvae. Both extract mixtures indicated synergistic joint action at both $\mathrm{LC}_{50}$ and $\mathrm{LC}_{95}$ levels (Table 3). Dadang and Prijono (2011) reported that JLP and FPB methanolic extract mixtures at 1:2, 1:1, and 2:1 concentration ratios were more toxic than FPB extract alone and had comparable activity with JLP extract alone but they did not perform quantative analysis of joint action of those extract mixtures.

Table 2. Results of probit analysis of $C$. pavonana larval mortality treated with hexane extract of $P$. retrofractum fruits and $T$. vogelii leaves and their mixture in contact tests, $24 \mathrm{~h}$ after treatment

\begin{tabular}{lccc}
\hline Extract & $b \pm \mathrm{SE}^{\mathrm{a}}$ & $\mathrm{LC}_{50}(95 \% \mathrm{CI})^{\mathrm{b}}(\%)$ & $\mathrm{LC}_{95}(95 \% \mathrm{CI})^{\mathrm{b}}(\%)$ \\
\hline$P$. retrofractum (JLP) & $4.32 \pm 0.43$ & $0.80(0.70-0.95)$ & $1.92(1.44-3.31)$ \\
T. vogelii (FPB) & $2.68 \pm 0.37$ & $1.27(0.96-2.47)$ & $5.20(2.60-44.38)$ \\
JLP + FPB (1:1) & $3.76 \pm 0.54$ & $1.16(1.04-1.37)$ & $3.18(2.36-5.37)$ \\
\hline
\end{tabular}

${ }^{\mathrm{a}} b$ : slope of the probit line, SE: standard error.

${ }^{\mathrm{b}} \mathrm{CI}$ : confidence interval.

Table 3. Joint action of $P$. retrofractum $(\mathrm{Pr})$ dan $T$. vogelii $(\mathrm{Tv})$ extract mixtures $(1: 1)$ on $C$. pavonana larvae in leaf-dipping and contact tests

\begin{tabular}{|c|c|c|c|c|c|}
\hline $\begin{array}{l}\text { Extract } \\
\text { mixtures }^{\text {a }}\end{array}$ & $\begin{array}{l}\text { Assessment } \\
\text { time }(\mathrm{HAT})^{\mathrm{b}}\end{array}$ & $\begin{array}{l}\text { Level of } \\
\text { toxicity }\end{array}$ & $\begin{array}{l}\text { Expected } \\
\mathrm{LC}_{\mathrm{x}}(\%)^{\mathrm{c}}\end{array}$ & $\begin{array}{l}\text { Co-toxicity } \\
\text { ratio at } \mathrm{LC}_{\mathrm{x}}^{\mathrm{c}}\end{array}$ & $\begin{array}{c}\text { Indication of } \\
\text { joint action }\end{array}$ \\
\hline \multicolumn{6}{|l|}{ Feeding test } \\
\hline \multirow[t]{2}{*}{$\operatorname{Pr}+$ Tv hex } & 72 & $\mathrm{LC}_{50}$ & 0.19 & 1.27 & Synergistic \\
\hline & & $\mathrm{LC}_{95}$ & 0.39 & 1.50 & Synergistic \\
\hline \multirow[t]{2}{*}{$\operatorname{Pr}+\mathrm{Tv}$ met } & 72 & $\mathrm{LC}_{50}$ & 0.37 & 2.31 & Synergistic \\
\hline & & $\mathrm{LC}_{95}$ & 0.87 & 2.29 & Synergistic \\
\hline \multicolumn{6}{|l|}{ Contact test } \\
\hline \multirow[t]{2}{*}{$\operatorname{Pr}+$ Tv hex } & 24 & $\mathrm{LC}_{50}$ & 1.31 & 1.13 & Synergistic \\
\hline & & $\mathrm{LC}_{95}$ & 2.99 & 0.94 & Antagonistic \\
\hline
\end{tabular}

ahex: hexane extract, met: methanol extract, all mixures were in $1: 1$ concentration ratios.

${ }^{\mathrm{b}} \mathrm{HAT}$ : hours after treatment.

${ }^{c}$ Expected $\mathrm{LC}_{\mathrm{x}}$ and co-toxicity ratio at $\mathrm{LC}_{\mathrm{x}}$ were calculated according to Robertson \& Smith (1984) as described in Materials and Methods. 
In contact tests, $\mathrm{LC}_{50}$ and $\mathrm{LC}_{95}$ of JLP and FPB hexane extract mixture were more or less in between those of single FPB and JLP extracts (Table 2 ). This mixture indicated synergistic action on $C$. pavonana larvae at the $\mathrm{LC}_{50}$ level but antagonistic at the $\mathrm{LC}_{95}$ level. At higher concentrations, variation in the difference of penetration rates among JLP and FPB active compounds through the insect cuticle, as assumed above, was probably wider than that at lower concentrations. As such, the proportion of some active compounds that penetrated the insect cuticle more slowly was less than that in the original extract mixture. This might result in antagonistic effect.

FPB leaves containing rotenoids, primarily deguelin, tephrosin, and rotenone, have long been known for their insecticidal activity both as stomach and contact poison (Delfel et al., 1970; Stevenson et al., 2012; Zhang et al., 2020. The lethal effect of rotenone is due to its action as a cellular repiratory poison through the inhibition of electron transfer between NADH dehydrogenase and coenzyme $\mathrm{Q}$ at complex I in mitochondria (Hollingworth 2001). This causes a significant reduction in ATP production which eventually leads to insect death.

Previously, JLP extract has been reported to act as a stomach poison (being active through feeding treatment) against European earwigs Forficula auricularia (Assabgui et al., 1997), cabbage head caterpillar, Crocidolomia pavonana, and diamondback moth Plutella xylostella (Zarkani et al., 2009; Dadang \& Prijono, 2011). This extract has also been reported to have contact action against some sucking pests including green stinkbug Nezara viridula (Hasnah \& Rusdy, 2015), papaya mealybug Paracoccus marginatus (Asnan et al., 2015), tea mosquito bug Helopeltis antonii (Indriati et al., 2015), and rice brown planthopper Nilaparvata lugens (Nuryanti et al., 2018).

JLP fruits have been reported to contain more than 10 piperamides, including guineensine, pipercide, and retrofractamide $\mathrm{A}$, which possess methylenedioxyphenyl group(s) (Kikuzaki et al. 1993; Parmar et al. 1997). It seems that these compounds contributed to the synergistic activity of FPB and JLP extracts reported in this study, especially in feeding tests. The presence of a methylenedioxyphenyl group is a characteristic of insecticide synergists which can inhibit cytochrome $\mathrm{P} 450$ that metabolizes toxic compounds in the body to lesser toxic substances (Bernard \& Philogène 1993). The inhibition of this enzyme allows toxic compounds in the mixture to retain their activity.

\section{Antifeedant Activity}

The treatment with both FPB and JLP hexane extract at $\mathrm{LC}_{25}$ to $\mathrm{LC}_{70}$ reduced feeding by $C$. pavonana larvae. The amount of treated leaves eaten by $C$. pavonana larvae was much less than that of their respective control (Table 4 and Table 5). The feeding reduction increased with the increase in extract concentration but differences in feeding reduction among extract concentration treatments of both extracts were not statistically significant due to large variations in feeding activity (Table 4 and Table 5).

Table 4. Effect of FPB hexane extract on feeding activity of $C$. pavonana larvae in a choice-test

\begin{tabular}{|c|c|c|c|c|}
\hline \multirow{2}{*}{$\begin{array}{l}\text { Concentration } \\
(\%, w / v)\end{array}$} & \multicolumn{2}{|c|}{$\begin{array}{l}\text { Leaf area eaten }\left(\mathrm{mm}^{2}\right) \\
(\text { Mean } \pm \mathrm{SD})\end{array}$} & \multirow[t]{2}{*}{$P^{\mathrm{a}}$} & \multirow{2}{*}{$\begin{array}{l}\text { Antifeedant effect } \\
(\text { Mean } \pm \text { SD) } \\
(\%)^{\mathrm{b}}\end{array}$} \\
\hline & Control & Treatment & & \\
\hline $\mathrm{LC}_{25}(0.10)$ & $62.47 \pm 31.89$ & $20.65 \pm 8.91$ & 0.046 & $45.9 a \pm 26.5$ \\
\hline $\mathrm{LC}_{40}(0.12)$ & $49.82 \pm 41.37$ & $6.49 \pm 2.77$ & 0.086 & $52.9 \mathrm{a} \pm 45.2$ \\
\hline $\mathrm{LC}_{55}(0.15)$ & $38.96 \pm 23.61$ & $8.65 \pm 4.98$ & 0.044 & $58.4 a \pm 20.2$ \\
\hline $\mathrm{LC}_{70}(0.18)$ & $44.58 \pm 22.45$ & $5.70 \pm 4.23$ & 0.015 & $79.6 a \pm 17.3$ \\
\hline
\end{tabular}

${ }^{a}$ In each concentration, leaf area eaten in the treatment is significantly different from its control if $P<0.05$ (paired $t$-test).

${ }^{b}$ Means followed by the same letter are not significantly different (Tukey test, $\alpha=0.05$ ).

Table 5. Effect of JLP hexane extract on feeding activity of $C$. pavonana larvae in a choice-test

\begin{tabular}{|c|c|c|c|c|}
\hline \multirow{2}{*}{$\begin{array}{l}\text { Concentration } \\
(\%, \mathrm{w} / \mathrm{v})\end{array}$} & \multicolumn{2}{|c|}{$\begin{array}{l}\text { Leaf area eaten }\left(\mathrm{mm}^{2}\right) \\
(\text { Mean } \pm \mathrm{SD})\end{array}$} & \multirow[t]{2}{*}{$P^{\mathrm{a}}$} & \multirow{2}{*}{$\begin{array}{l}\text { Antifeedant effect } \\
(\text { Mean } \pm \text { SD) } \\
(\%)^{\mathrm{b}}\end{array}$} \\
\hline & Control & Treatment & & \\
\hline $\mathrm{LC}_{25}(0.075)$ & $51.5 \pm 5.9$ & $18.8 \pm 26.3$ & 0.04 & $42.1 \mathrm{a} \pm 19.2$ \\
\hline $\mathrm{LC}_{40}(0.100)$ & $68.8 \pm 7.2$ & $16.0 \pm 23.4$ & 0.01 & $60.3 a \pm 22.1$ \\
\hline $\mathrm{LC}_{55}(0.125)$ & $71.0 \pm 7.4$ & $11.1 \pm 30.2$ & 0.02 & $66.2 \mathrm{a} \pm 31.1$ \\
\hline $\mathrm{LC}_{70}(0.160)$ & $82.1 \pm 6.6$ & $9.7 \pm 51.3$ & 0.04 & $72.4 a \pm 27.9$ \\
\hline
\end{tabular}

${ }^{a}$ In each concentration, leaf area eaten in the treatment is significantly different from its control if $P<0.05$ (paired $t$-test).

${ }^{\mathrm{b}}$ Means followed by the same letter are not significantly different (Tukey test, $\alpha=0.05$ ). 
The decreased feeding activity of $C$. pavonana larvae on treated broccoli leaves can be the result of stimulation of deterrent sense cells which may be complemented by suppression of phagostimulant sense cells in insect taste organs (Koul 2008). Intoxication of $C$. pavonana larvae by FPB and JLP extracts, as initially indicated by the insect decreased mobility, could further reduced feeding activity. Moreover, weak insects due to poisoning and starvation would be more vulnerable to attacks by their natural enemies. Thus, the treatment with toxic plants extracts which also possess antifeedant activity is expected to reduce pest population and crop damage substantially.

\section{CONCLUSION}

In the feeding treatment, $P$. retrofractum $(\mathrm{Pr})$ and $T$. vogelii $(\mathrm{Tv})$ hexane extracts had strong insecticidal activity against $C$. pavonana larvae $\left(\mathrm{LC}_{95}<0.5 \%\right)$ and were more active their respective methanol extracts. Pr and Tv hexane extract had a moderate and a rather weak contact effect, respectively, on $C$. pavonana larvae. In feeding tests, $\operatorname{Pr}+\mathrm{TV}(1: 1)$ hexane and methanol extract mixtures indicated synergistic joint effect both at $\mathrm{LC}_{50}$ and $\mathrm{LC}_{95}$ level, whereas in the contact test, the mixture of $\operatorname{Pr}+\operatorname{Tv}(1: 1)$ hexane extract was synergistic at the $\mathrm{LC}_{50}$ level but antagonistic at the $\mathrm{LC}_{95}$ level. In choice tests, antifeedant effects of Pr and Tv hexane extracts at $\mathrm{LC}_{25}$ to $\mathrm{LC}_{70}$ levels on $C$. pavonana larvae followed a concentration-dependent manner.

\section{ACKNOWLEDGEMENTS}

The authors thank the Department of Plant Protection, Bogor Agricultural University for funding support of this study through Project Grant. We also thank Mr. Agus Sudrajat for his technical assistance.

\section{REFERENCES}

Asnan TAW, Sartiami D, Anwar R, \& Dadang. 2015. Keefektifan ekstrak Piper retrofractum Vahl., Anonna squamosa L. dan Tephrosia vogelii
Hook. serta campurannya terhadap imago kutu putih pepaya Paracoccus marginatus Williams \& Granara de Willink (Hemiptera: Pseudococcidae). J. Entomol. Indon. 12(2): 80-90.

Assabgui R, Lorenzetti F, Terradot L, Regnault-Roger C, Malo N, Wiriyachitra P, Sanchez-Vindas PE, San Roman L, Isman MB, Durst T, \& Arnason JT. 1997. Efficacy of botanicals from the Meliaceae and Piperaceae. Pp 38-48 in Hedin PA, Hollingworth RM, Masler EP, Miyamoto J, \& Thompson DG (Eds.). Phytochemicals for Pest Control. Washington DC: ACS.

Bernard CB, \& Philogène BJR. 1993. Insecticide synergists: role, importance, and perspectives. J. Toxicol. Environ. Health 38(2): 199223.

Chen CH. 2020. Xenobiotic Metabolic Enzymes: Bioactivation and Antioxidant Defense. Cham: Springer Nature.

Dadang, \& Prijono D. 2008. Insektisida Nabati: Prinsip, Pemanfaatan, dan Pengembangan. Bogor: Departemen Proteksi Tanaman, Institut Pertanian Bogor.

Dadang, \& Prijono D. 2011. Pengembangan teknologi formulasi insektisida nabati untuk pengendalian hama sayuran dalam upaya menghasilkan produk sayuran sehat. J Ilmu Pertan. Indon. 16(2): 100-111.

Delfel NE, Tallent WH, Carlson DG, \& Wolff IA. 1970. Distribution of rotenone and deguelin in Tephrosia vogelii and separation of rotenoidrich fractions. J. Agric. Food Chem. 18(3): 385-390.

Gaskins MH, White GA, Martin FW, Delfel NE, Ruppel EG, \& Barnes DK. 1972. Tephrosia vogelii: A source of rotenoids for insecticidal and piscicidal use. Technical Bulletin No. 1445. Washington, D.C.: Agricultural 
Research Service, United States Department of Agriculture.

Hasnah, \& Rusdy A. 2015. Pengaruh ekstrak buah cabe jawa (Piper retrofractum Vahl.) terhadap perkembangan dan mortalitas kepik hijau. J. Floratek 10(2): 87-96.

Heyne K. 1987. Tumbuhan Berguna Indonesia. Jilid 2. Diterjemahkan dari De Nuttige Planten van Indonesie oleh Badan Litbang Kehutanan. Jakarta: Yayasan Sarana Wana Jaya.

Hollingworth RM. 2001. Inhibitors and uncouplers of mitochondrial oxidative phosphorylation. In: Krieger R, Doull J, Ecobichon D, Gammon D, Hodgson. (eds) Handbook of Pesticide Toxicology. Vol 2. Academic Press, San Diego, pp 1169-1227.

Houghton PJ, \& Raman A. 1998. Laboratory Handbook for the Fractionation of Natural Extracts. London: Chapman \& Hall.

Indriati G, Dadang, \& Prijono D. 2015. Aktivitas insektisida ekstrak buah cabai jawa (Piper retrofractum) terhadap Helopeltis antonii (Hemiptera: Miridae). J. Penel. Tan. Ind. 21(1): 35-42.

Kamanula JF, Sileshi G, Belmain SR, Sola P, Mvumi B, Nyirenda GKC, Nyirenda SPN, \& Stevenson PC. 2011. Farmers' pest management practices and pesticidal plant use for protection of stored maize and beans in Southern Africa. Int. J. Pest Manag. 57(1): 41-49.

Kikuzaki H, Kawabata M, Ishida E, Akazawa Y, Takei Y, \& Nakatani N. 1993. LC-MS analysis and structural determination of new amides from Javanese long pepper (Piper retrofractum). Biosci. Biotechnol. Biochem. 57(8): 1329-1333.

Koul O. 2008. Phytochemicals and insect control: an antifeedant approach. Crit. Rev. Plant Sci. 27: 1-24.
Matsumura F. 1985. Toxicology of Insecticides. 2nd ed. New York: Plenum Press.

Miyakado M, Nakayama I, \& Ohno N. 1989. Insecticidal unsaturated isobutylamides from natural products to agrochemical leads. Pp. 173-187 in Arnason JT, Philogene BJR, \& Morand P (Eds.). Insecticides of Plant Origin. Washington, D.C.: ACS.

Nurfajrina A, \& Prijono D. 2015. Keefektifan ekstrak lima spesies Piper (Piperaceae) untuk meningkatkan toksisitas ekstrak Tephrosia vogelii terhadap hama kubis Crocidolomia pavonana. Pp. 88-96 in Strategi Perlindungan Tanaman dalam Memperkuat Sistem Pertanian Nasional Menghadapi ASEAN Free Trade Area (AFTA) dan ASEAN Economic Community. Prosiding Seminar Nasional Perlindungan Tanaman II; Bogor, 13 Nov 2014. Bogor: Pusat Kajian Pengendalian Hama Terpadu, Institut Pertanian Bogor.

Nuryanti NSP, Martono E, Ratna ES, \& Dadang. 2018. The bioactivities of selected Piperaceae and Asteraceae plant extracts against brown planthopper (Nilaparvata lugens stål.). J. ISSAAS 24(2):70-78.

Ott RL, \& Longnecker M. 2016. An Introduction to Statistical Methods and Data Analysis. 7th ed. Boston: Cengage Learning.

Parmar VS, Jain SC, Bisht KS, Jain R, Taneja P, Jha A, Tyagi OD, Prasad AK, Wengel J, Olsen CE, \& Boll PM. 1997. Phytochemistry of the genus Piper. Phytochemistry. 46(4):597673.

Prakash A, \& Rao J. 1997. Botanical Pesticides in Agriculture. Boca Raton: CRC Press.

Prijono D. 1999. Prospek dan strategi pemanfaatan insektisida alami dalam PHT. Pp. 1-7 in Nugroho BW, Dadang, \& Prijono D (Eds.). Bahan Pelatihan Pengembangan dan 
Pemanfataan Insektisida Alami; Bogor, 9-13 Agustus 1999. Bogor: Pusat Kajian Pengendalian Hama Terpadu IPB.

Prijono D, \& Hassan E. 1992. Life cycle and demography of Crocidolomia binotalis Zeller (Lepidoptera: Pyralidae) on broccoli in the laboratory. Indon. J. Trop. Agric. 4(1):18-24.

Prijono D, Sudiar JI, \& Irmayetri. 2006. Insecticidal activity of Indonesian plant extracts against the cabbage head caterpillar, Crocidolomia pavonana (F.) (Lepidoptera: Pyralidae). J. ISSAAS. 12(1):25-34.

Robertson JL, Jones MM, Olguin E, \& Alberts B. 2017. Bioassays with Arthropods. 3rd ed. Boca Raton: CRC Press.

Robertson JL, Preisler HK, \& Russell RM. 2003. PoloPlus: Probit and Logit Analysis User's Guide. Petaluma: LeOra Software.

Robertson JL, \& Smith KC. 1984. Joint action of pyrethroids with organophosphorus and carbamate insecticides applied to western spruce budworm (Lepidoptera: Tortricidae). J. Econ. Entomol. 77(1):16-22.

SAS Institute. 2018. SAS ${ }^{\circledR}$ Studio Release 3.8. Cary: SAS Institute.

Scott IM, Jensen HR, Philogene BJR, \& Arnason JT. 2008. A review of Piper spp. (Piperaceae) phytochemistry, insecticidal activity and mode of action. Phytochem. Rev. 7: 65-75.

Stevenson PC, \& Belmain SR. 2017. Tephrosia vogelii: a pesticide of the future for African farming. Bol. SEEA No. 2: 19-22.
Stevenson PC, Isman MB, \& Belmain SR. 2017. Pesticidal plants in Africa: A global vision of new biological control products from local uses. Ind. Crops Prod. 110: 2-9.

Stevenson PC, Kite GC, Lewis GP, Forest F, Nyirenda SP, Belmain SR, Sileshi GW, \& Veitch NC. 2012. Distinct chemotypes of Tephrosia vogelii and implications for their use in pest control and soil enrichment. Phytochemistry. 78: 135-146.

Sunarno B. 1997. Tephrosia vogelii JD Hooker. Pp. 248-251 in Hanum IF \& van der Maesen LJG (Eds.). Plant Resources of South-East Asia No. 11: Auxiliary Plants. Leiden: Backhuys Publisher.

Utami D, \& Jansen PCM, 1999. Piper L. Pp. 183-188 in de Guzman CC \& Siemonsma JS (Eds.). Plant Resources of South-East Asia No. 13: Spices., Leiden: Backhuys Publisher.

Yooboon T, Pengsook A, Ratwatthananon A, Pluempanupat $\mathrm{W}$, \& Bullangpoti V. 2019. A plant-based extract mixture for controlling Spodoptera litura (Lepidoptera: Noctuidae). Chem. Biol. Technol. Agric. 6(5): 1-10.

Zarkani A, Prijono D, \& Pudjianto. 2009. Pengujian ekstrak Piper retrofractum sebagai insektisida nabati terhadap Crocidolomia pavonana dan Plutella xylostella serta keamanannya terhadap Diadegma semiclausum. J. Akta Agrosia 12(1): 35-44.

Zhang PW, Qin DQ, Chen JJ, \& Zhang ZX. 2020. Plants in the genus Tephrosia: valuable resources for botanical insecticides. Insects 11(721): 1-18.

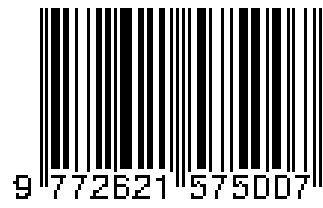

